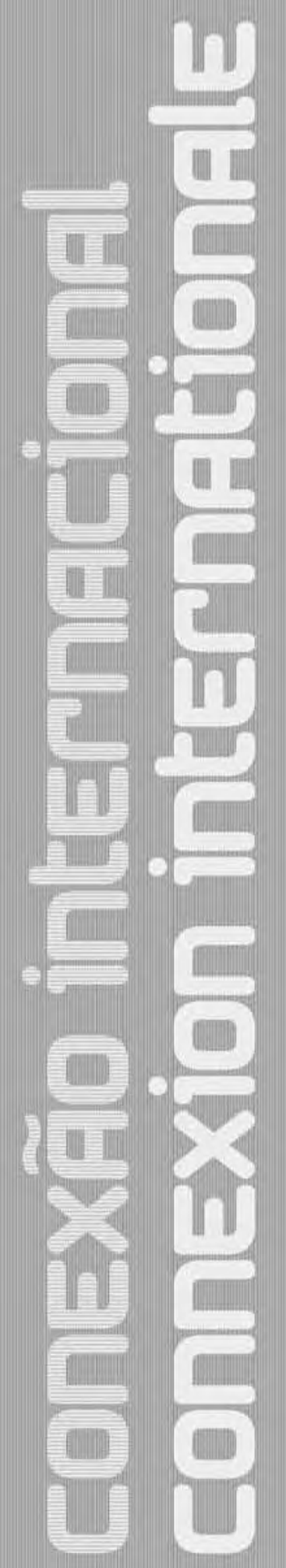




\section{História, memória e desaparecimento: o vídeo entre arquivo e cálculo}

Françoise Parfait*

Thierry Kuntzel Inverno (A morte de Robert Walser), 1990

Instalação, ciclos de 5 minutos 30 segundos.
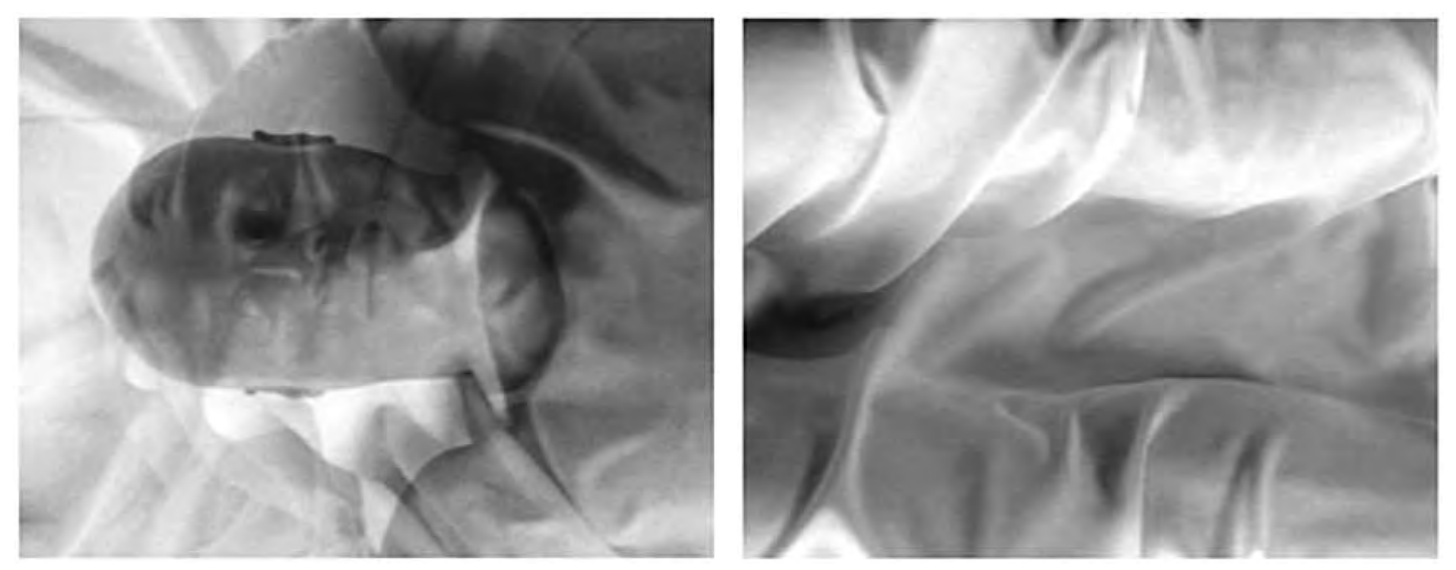

*Françoise Parfait é doutora em Artes e professora da Universidade Sorbonne Paris 1. Suas pesquisas concernem à questão das imagens no campo da arte contemporânea. Publicou Video: um art contemporain. Paris: editions du regard, 2001, o catálogo Collection Nouveaux Médias/Installations, Centre Pompidou, 2006; catálogo David Claerbout - The Shape of Time, 2008). É membro do coletivo 'Suspended spaces' (2007) plataforma de pesquisa em artes. 


\section{Silêncio.}

Uma tela bastante comprida para uma imagem muito precisa, à beira do desaparecimento, mas apenas à beira. Três projeções lado a lado, configurando um tríptico, mostram ao centro uma imagem que representa um corpo deitado, capturado em um movimento da câmera; à direita e à esquerda desta imagem móvel, evoluindo em simetria, dois monocromos variam de intensidade e de cor, passando do branco azulado ao preto pelas nuances de azul mais ou menos saturado. Enquanto o tempo transcorre pelas laterais que possuem a única cor do vídeo, "o azul do céu", mas também o azul da televisão, da incrustação², da imagem eletrônica, a imagem do centro permanece em preto e branco, e descreve o corpo de um homem negro, parcialmente recoberto por um véu de tecido branco. A impressão do preto e branco é tão presente que ela confunde a natureza de negativo ou positivo da imagem; essa incerteza é acentuada pelos movimentos de varredura sobre o corpo deitado, que parecem sondar, pelas aproximações sucessivas, o interior de um túmulo. O corpo, filmado de muito perto, permanece imóvel. Simplesmente, em um determinado momento em que o movimento da câmera para sobre o rosto, podemos ver o abrir e o fechar dos olhos do modelo. Este único acontecimento confirma a suspeita sobre o estado do corpo: vivo. Liberto de um drama que estaria relacionado ao realismo ontológico da imagem, o espectador pode concentrar-se em outro drama que a imagem coloca em cena: o próprio desaparecimento no centro do seu tema, um corpo mudo, porém sereno, alongado, pousando todo seu peso, "re-pousado," "de-pousado", já dentro de um lençol, comprimido pelo enquadramento, contido pelo movimento lateral. Essa varredura repetida, porém a cada passagem diferente, recorda o trabalho de um scanner: programação do ponto de vista e corte do corpo em lâminas, em cortes horizontais que se referem às profundidades sucessivas da carne. $O$ acesso à visibilidade do corpo muda a cada passagem; de uma visão direta sobre a pele, superfície exterior, passamos ao jogo de transparência e opacidade que faz com que o corpo se perca nas pregas do tecido, ainda que este último "cole-se à sua pele", aspirado que é pelas inspirações do modelo. Corpo de carne, triunfante e esplêndido, ou corpo fantasma, redobrado pela brancura da morte ou do lençol, esse corpo é um corpo rememorado, trabalhado através do modelo de um imaginário médico com o qual estamos familiarizados, mas que reconduz, com ele, a todos os túmulos da literatura, a neve da noite fatal de Robert Walser ${ }^{3}$, a ausência da imagem da vera-icona, no princípio da fotografia, do cinema, do vídeo. Este cântico videográfico - uma divisória, um ritmo, uma 
cor, uma tonalidade - toma-se à beira da linguagem, à beira do abismo, à beira do perigo iminente. A imagem toma corpo e se dispersa, aparece no sopro do movimento, depois desaparece no branco do tecido, do suporte, da tela. A matéria afeta a precisão da lâmina e se confunde com a estrutura em flocos. Como a história, o homem se realiza sob nossos olhos e, sobretudo, em nosso espírito, nossa memória e dessa forma "damos imagem humana ao abismo, chamando-o nascer e morrer"4.

\section{Visão histórica de uma mídia}

Esta peça de Thierry Kuntzel (1948, França) inscreve-se dentro de uma história: uma história das técnicas e das imagens. De certa maneira, ela faz a síntese entre uma história ancestral das imagens e uma tecnologia de ponta, visto que a câmera é controlada por computador. Com efeito, a imagem aqui é considerada como traço de um referente, de uma realidade, é análoga ao corpo de Ken Moody, mas ao mesmo tempo ela o consome em ausência e em diferença. A imagem não é a coisa, mas atesta sua ausência. A esta consideração ontológica banal, porém muito teórica, Thierry Kuntzel acrescenta uma dimensão física e material, tornando visível a passagem da presença à ausência, no próprio corpo da imagem. Ele o obtém pelos meios de uma técnica em um dado momento de sua história: o vídeo e a informática, meios técnicos mantidos pela herança da pintura, da fotografia e do cinema. Toda a história das origens da representação da figura humana na pintura (do ícone à máscara mortuária) e na fotografia (do santo sudário ao véu de Verônica) está inscrita silenciosamente nessa peça, até a homenagem ao fotógrafo Robert Mapplethorpe, evocado pelo seu modelo Ken Moody. Inverno é, de certa maneira, a metáfora do que é toda fotografia, um túmulo, ode poética à memória de um "isso foi", do qual Barthes definitivamente traçou os contornos. Para produzir esta sensação de afastamento, Thierry Kuntzel utiliza o vídeo, como faz desde seus primeiros trabalhos, porque ele é desaparecimento, em sua materialidade e em seu destino; a fragilidade do suporte e de sua conservação fez do vídeo um meio falho e inconstante, em vias de desaparecimento inevitável, em trabalho de apagamento contínuo, numa perda permanente dele mesmo. Não se deve esquecer que o número de fitas cassete dos anos 1960 e 1970, que não foram bem conservadas ou restauradas a tempo, caíram no esquecimento por conta do desaparecimento da imagem e do som. Em Inverno, a imagem não foi alterada 
pelo tempo, mas é a própria representação que figura seu desaparecimento. A dramatização plástica (a brancura que envolve a figura, a transparência dos véus, a postura cadavérica do corpo), a matéria videográfica (o chuvisco do próprio material de que é feita a imagem), e os movimentos tão lentos, lisos e implacáveis, participam da construção de uma representação mental que acentua e confirma a sensação de desaparecimento. O artista-escrivão, ou o artista-poeta já descrevera em fins dos anos 1970 o que se passou entre ele e o vídeo: "Para ele, que conhecia da imagem seus congelamentos da representação - pintura, fotografia, cinema, televisão -, o vídeo foi um choque: choque na medida em que ele se encontrou, de repente alienado. E por trás de todo reconhecível, de toda designação, de toda captura, algo de obscuro que se buscava por intermédio dos filmes - outra circulação, uma capacidade desconhecida, um espaço de deslizamento, de transformações, de rastros, um tempo liberto dos constrangimentos narrativos cronológicos - então era isso: um vai-e-vem luminoso, uma varredura, uma pulsação de tramas, uma superfície pulsante." ${ }^{5}$ Os "congelamentos da representação", como nomeou Thierry Kuntzel, derretem como o gelo e cantam o espaço das transformações. Eles derretem também como um bloco de cera, pois "só na cera, a memória guarda vestígio de seus rastros aparentes, enterrados, vindos, repartidos e desaparecidos".

Vemos desenhar-se nesta proposta mais do que a descrição de uma especificidade técnica, o contorno de uma estética que não tarda a ultrapassar o dispositivo vídeo stricto sensu para designar toda prática da imagem que esteja relacionada aos processos mentais da lembrança ao esquecimento e a todos os avatares da memória. O Wunderblock ${ }^{6}$ descrito por Freud servirá para comparar uma superfície eletrônica que deixa aflorar, por camadas e traços sucessivos, imagens que se apresentam ou desaparecem, ao cérebro quando quer se lembrar e recordar de uma sensação ou um evento no presente da consciência. Como o vídeo, a memória tem uma história da qual Frances Yates traçou as grandes etapas em A arte da memória’: a memória sempre precisou de técnicas para se exercer e, do grego Simonide ao vídeo, as técnicas de memória foram florescendo desde a História das histórias dos homens. A mais recente, que parece ter resolvido o problema do armazenamento e da conservação, de toda e todas as memórias é a informática, com todo o crédito que lhe concedemos ou a suspeita que the atribuímos como fazemos a cada vez que uma solução é apresentada como definitiva a esta ou aquela questão que inquieta uma cultura. 
O vídeo apareceu à margem da informática, mas prefigura certos traços dela, em particular no modo de inscrição da informação luminosa sobre as telas tramadas de pixels. É o que permite associar rapidamente o trabalho vinculado às imagens analógicas - captura, enquadramento, movimento, iluminação - àquele relacionado ao cálculo e à digitalização: os sintetizadores e outros processadores de efeito mais ou menos sofisticados permitiram manipular a imagem, e os programas de captura auxiliados por computador permitiram dar ao enquadramento da imagem formas e ritmos absolutamente inéditos; Garry Hill e Thierry Kuntzel, entre outros, utilizaram rapidamente esses meios. O trabalho "em tempo real", que é uma particularidade do dispositivo digital, já encontrou seus modelos empíricos na restauração ao vivo da imagem (realidade?) captada em vídeo, e da 'tele-visão', depois do 'tele-fone'. Se o vídeo é predestinado a ser absorvido pelo grande todo digital (e isso é não somente inevitável como já realizado), o videográfico - enquanto estabelecimento das condições materiais de uma estética -, Ihe sobreviverá ou, antes, seus traços serão eles mesmos integrados aos modos de pensamento e às possibilidades técnicas da informática; isso já é visto nas configurações das câmeras de vídeo digitais do início do século e seus efeitos de vídeo pré-programados. Deslocando-se para o campo digital, o vídeo fecha um domínio conceitual para abrir outro. De "homem memorável" proveniente de uma história e da imperfeição de seus esquecimentos, passamos então ao "homem calculável" de medida e de avaliação, sendo a genética, por exemplo, um outro instrumento.

Se o vídeo, em sua própria estrutura, tem capacidade de tratar dos movimentos psíquicos da mesma maneira que faz o cérebro - armazenar informação, fazê-la aparecer, tratar do passado no presente, a atualidade ao vivo... - então não é de se espantar que ele seja particularmente inclinado para o modo pelo qual a história se constrói a partir dos arquivos que produz, em particular, evidentemente, dos arquivos de imagens. E que ele se interesse, por intermédio dos artistas, pela maneira como a memória é elaborada partir das imagens do mundo tal como elas são difundidas pela televisão, e pela maneira como essas imagens constituem os arquivos de uma sociedade e de uma cultura em um dado momento da história, o da segunda metade do século XX. A televisão produz o essencial dos arquivos contemporâneos, além de produzir os modelos de comportamento. Qual é a relação que se estabelece entre o trabalho de elaboração da memória que cada um faz por sua própria conta, e aquela da história tal qual é escrita a partir das mídias? De que modo os artistas colocam essas questões quando trabalham 
com as tecnologias eletrônicas e informáticas? Como o médium vídeo, esse intermediário sempre frágil e efêmero, participou da elaboração de uma estética do desaparecimento que o cinema já havia desenvolvido graças a suas qualidades fenomenológicas? Em que os arquivos midiáticos podem constituir documentos (etimologicamente "o que serve para educar")? E a partir de quando uma imagem constitui-se como documento? Está dentro da competência da arte concorrer, como lugar de discurso, com o arquivo, o "domínio das coisas ditas" como o denomina Michel Foucault? A arte pode ter valor de documento, ela pode ser documental? Como essa estética do desaparecimento e o regime de rastros que a acompanha são tratados no início do século XXI pelas novas gerações de artistas que adotam, por vezes em relação às questões da memória e da história em geral, algumas posturas amnésicas ou no mínimo negligentes? Atravancados pelos "deveres de memória"9 que frequentemente são substituídos por ações envolvidas e responsáveis, e escaldados pelas falsificações midiáticas que lançam pesadas suspeitas sobre a relação da informação com a verdade, os artistas preferem, por vezes, suspender ingenuamente os problemas e esquecê-los. Indiferença.

O contorno das problemáticas artísticas contemporâneas desenhado por essas numerosas questões não encontra necessariamente as respostas nas obras; ao menos essas interrogações estão submetidas à experimentação dentro de dispositivos muito diferentes uns dos outros (dos gestos técnicos e conceituais mais simples aos mais sofisticados). Se o presente se constrói em torno do encontro entre "os lençóis ${ }^{10}$ de passado e as camadas de realidade", para citar Gilles Deleuze, é impossível fazer a economia de uma memória que não se compromete necessariamente com o dever e a devoção, mas antes com a atribuição de significado a um presente que resiste por vezes com todas as forças a se comprometer com tal empreitada. Se o vídeo tem qualquer relação com a história, a memória, o arquivo e a reminiscência, é o interior mesmo de uma lógica paradoxal que o define: preocupado essencialmente com o presente, confinado ao esquecimento em sua acepção televisiva, evanescente por natureza. Assim, "o eterno presente do eletrônico tende a obstruir toda atividade de percepção suscetível de alimentar a memória"11. Ou, dita de outra maneira por Dominique Avron: "Imagens e sons da televisão não se conservam; eles se desejam e se rejeitam, eles se envolvem e se caçam uns aos outros como palavras fúteis. As questões da conservação dos fatos ou da aquisição do saber pela televisão, da relação com a história, da passagem dos arquivos escritos para os bancos audiovisuais, são comandadas e como se corrompidas por essa qualidade 
física da mídia" ${ }^{12}$. Como então restituir, sem recuo e sem pensamento histórico, a densidade temporal e mnemônica nas imagens que apareceram no presente mesmo de sua atualidade?

\section{0 vídeo, $\mathrm{o}$ arquivo e a história}

Sobre o título epônimo Art of Memory, Woody Vasulka (1937, República Checa/EUA) realiza em 1987 um vídeo complexo, feito a partir de imagens de arquivos, imagens filmadas pelo artista e manipulações informáticas sofisticadas. Os temas tratados por Vasulka são as guerras do século $X X$ tais como os documentários e imagens de arquivos testemunharam: a Guerra Civil Espanhola, a Revolução Russa, a Segunda Guerra Mundial, a Bomba Atômica. O filme, com uma duração de 36 minutos, trata essas imagens de arquivo em preto e branco como objetos esculturais (as imagens animam por seus deslocamentos e ao desposar suas formas, espécies de padrões com volume), postos na extensão de uma paisagem desértica (o Novo-México, mito de origem e local da land art, identidade de uma lembrança e de um lugar, tal como o chama Frances Yates a propósito de Simonide); mas trata-se também de um lugar sem lugar e sem duração, um não-lugar, de certa maneira, a-histórico, aonde vão se jogar justamente as imagens da história. A esses elementos, vem juntar-se a silhueta de uma espécie de anjo sentado, figura mítica pendurada em um precipício. Um homem de face enrugada tenta prender a atenção em quem ele acaba atirando pedras. As imagens deslizam umas sobre as outras, reconfigurando permanentemente um espaço metamórfico no qual as camadas de cor e as imagens de arquivo en abîme ${ }^{13}$ varrem e cobrem a paisagem real e, no entanto, abstrata do Oeste americano. Esta última confunde-se com a abstração de uma paisagem eletrônica; paisagem sem história, ou cuja história é passada fora dela, ela suporta nesse vídeo o peso das histórias trágicas do mundo, cujo som e fúria são percebidos na trilha sonora. Realidade e artifício disputam a superfície de uma imagem que se queria consciente de uma história e memória do medo. As imagens dos arquivos em preto e branco que vestem os "monumentos" postos sobre a paisagem desértica desfilam muito rápido, são muito pequenas para serem percebidas em seus detalhes e examinadas em seu conteúdo narrativo; elas têm função de ícone ou são imagens genéricas e se referem, de forma abrangente, a seu próprio tema. De certo ponto de vista, todas as imagens de arquivo se parecem, sobretudo quando o preto e o branco vêm justamente datar tudo o que se passou antes dos anos 1950 . 
E mesmo posteriormente, já que as notícias continuaram sendo rodadas em preto e branco até o fim dos anos 1970. Woody Vasulka mistura, em uma imagem comum, em um só um lugar comum, as imagens de cinema e de seu documentário, em uma relação de indiscernibilidade (como uma lembrança que não consegue se fixar ou tomar, de fato, forma) com as imagens videográficas tratadas pela informática: trabalho difícil de descrever na medida em que a imagem só é apreendida lá como nas turbulências de suas metáforas informáticas. Como sintetiza Raymond Bellour, que realizou uma análise muito completa deste vídeo, o espectador é submetido à "tensão que se produz entre corpo 'real' e 'corpo da trama', e deve "tentar delimitar em dois níveis o diálogo circular que amarra cinema e vídeo, como o que amarra o analógico e o digital14". Esse vídeo recicla as imagens de eventos do século XX através de um tratamento que lhes faz passar de um estado de documento a um estado de monumento; tornando essa passagem visualmente perceptível, Woody Vasulka realiza uma história que tende à arqueologia, como havia pontuado Foucault, o que significa que tende à 'descrição intrínseca do monumento' 15 '.

Todavia, o trabalho do artista não consiste em comentar a história com as ferramentas do historiador, mas antes, em criar novas visões, de pôr em perspectiva para além dos discursos que subentendem pesquisas específicas, que recorrem a métodos de abordagem que incluem a arte e suas descontinuidades. Vera Frenkel (Checoslováquia / Canadá) realizou com Body Missing (1994) uma instalação que permite justamente estabelecer relações inéditas entre restos e fragmentos de documentos históricos e os objetos e elementos dispostos ao redor e para as imagens, que são assim reprocessadas. Seu tema, cujo título indica a dimensão trágica, refere-se ao projeto que Hitler tinha de criar uma coleção de obras de arte para alimentar o museu de Linz, construído para glorificar o império que levava seu nome. Projeto de construção de um corpo simbólico (a transcendência da arte a serviço de uma ideologia) enquanto que, paralelamente, era conduzida, com uma obstinação igualmente louca, a empreitada de extermínio do corpo judeu, corpo que será devolvido à história amplamente dilacerado e assassinado. Para realizar este trabalho em seis partes, Vera Frenkel reuniu uma grande quantidade de arquivos documentais - fotografias, filmes, maquetes, discursos, entrevistas, listagens... - demonstrando a que ponto a elaboração da coleção, resultado de roubos, saques e espoliações, foi objeto de uma atenção extrema e registrada nos mínimos detalhes 
de sua implementação. Ela se propõe a associar diferentes documentos (abre caminhos, concentra-se num detalhe), nas fitas de vídeo exibidas nos monitores ordenados sobre pilhas de caixas para transporte de obras, caixas de luz grosseiramente construídas com madeira reciclada, e cadeiras que convidam o espectador a se sentar, por ser necessário mobilizar uma atenção toda particular para acessar esse trabalho. Cada vídeo corresponde a uma instalação que é uma etapa do percurso com seis estações. Os vídeos mostram fragmentos e visões parciais das obras primas confiscadas. Os documentos nunca são focalizados ou filmados em sua totalidade, o que sublinharia o efeito de eternidade das obras do passado, mas antes enfatiza a incompletude de um olhar atual sobre esses arquivos tratados em negativo (radiografia), varridos do olhar, repetidos, e misturados às imagens de ficção e de investigações. A essa profusão de imagens corresponde um comentário sempre deslocado em relação ao que é visto (deixando a encargo do espectador o cuidado de costurar momentaneamente os fragmentos de significação), no interior de cada instalação ou entre uma instalação e outra - posto que certos elementos são repetidos e recontextualizados de um vídeo a outro. A artista insiste sobre o fato de que um documento bruto não fala, ou antes, que ele fala por diferentes vozes e que é preciso testá-las para avaliar seu potencial de "verdade". Ela mostra (e aponta com o dedo) a imagem documentária para dizer que, na leitura e na interpretação, há um corpo, um sujeito e uma história. Ela insiste também sobre a forma como a arte pode, por sua vez, ser instrumentalizada para fins externos aos propósitos intrínsecos à obra (Hitler se utiliza da arte para valorizar emblematicamente sua política); é armar a arte de intenções (neste caso, prefigurando o modelo nazi) que não estão nela, mas cuja interpretação mal intencionada pode forçar-lhe o sentido. O trabalho de Vera Frenkel nos faz lembrar também que Hitler é talvez, antes de tudo, um artista fracassado, de qualquer modo frustrado, mas que não cessou de perseguir na realidade, e não sobre o plano simbólico, seu sonho mórbido de criação de um mundo à sua imagem.

Para além de um dever de memória, com seu cortejo de obrigações que carecem, por vezes, de explicações e de motivações - os rituais que comemoram os acontecimentos que a História quer homenagear são frequentemente vazios de seus conteúdos - é realmente para um trabalho de memória que estes artistas operam. A arte que, em si, não é nem boa nem má em termos morais, pode, em contrapartida, reunir as condições da revelação, não no sentido 
transcendental, mas simplesmente factual, de um desaparecimento e de um corpo desaparecido, e superar assim o medo do passado, do qual fala Virilio ${ }^{16}$. O melhor meio para se chegar a esse ponto é agarrar os vestígios desse passado a unhas e dentes, de reposicioná-los na cena do presente e de não dissimulá-los atrás de propósitos ideológicos excessivamente partidários, que consagrariam forçosa e definitivamente o luto de uma história gloriosa ou nem tanto. É o que fazem os artistas que se interessam por avaliar o estado pós-colonial das culturas ocidentais interrogando sobretudo seus modos de representação; dentre esses, os belgas, como Johan Grimonprez (1962, Bélgica). Ele inicia por considerar como as mídias orquestram nossa relação com as catástrofes, retomando a metáfora do poder e da fragilidade das nações ocidentais - que Wolf Vostell havia destilado em seus primeiros vídeos e, em particular, no Sun in your head, o avião e seu avatar helicóptero -, e a ideia anunciada por Virilio que cada tecnologia traz com ela seu acidente, ou seja, os meios de sua perda ou de sua catástrofe. Como se constitui uma "cultura da catástrofe"? Kobarweng or Where is your Helicopter? É um vídeo realizado em 1992 em que Johan Grimonprez evoca a maneira como foi percebida, em 1959, a chegada dos cientistas ocidentais em uma cidade distante de Nova Guiné, cujo acesso se dava apenas por via aérea. O medo, ligado a uma percepção particularmente aguda dos sons nessa cultura de floresta tropical úmida, foi a reação provocada por essas coisas vindas do céu que os aldeões jamais haviam visto antes. Acompanhados por uma trilha sonora particularmente presente (uivos de pássaros tropicais, pesados silêncios, barulho de avião), imagens de arquivo misturadas à imagens produzidas pelo artista tornam perceptível a estranheza desta situação onde duas culturas tão diferentes se interpenetram. Arquivos sobre a Nova Guiné, imagens simbólicas (queda de um objeto, água que pinga de uma torneira, chaleira), imagens vistas do avião, paraquedas, processamento em vídeo das imagens de arquivo (colorização, estroboscopia)... e um importante texto instala uma atmosfera que, ainda que sedutora, não perde sua dimensão crítica. Numa outra película, Dial H.I.S.T.O.R.Y (1997), Grimonprez convida ironicamente seus interlocutores para telefonar à História e saber notícias dela; é dos arquivos da televisão que ele toma emprestadas as imagens de sequestros de avião, atentados e ataques terroristas, tal como as informações foram difundidas a partir do fim dos anos 1960 . A História é feita pelas mídias, é o que as imagens e seus comentários afirmam claramente. Com um tom menos pedagógico que aquele de Harun Farocki quando esgota as estruturas ideológicas dos discursos que as mídias realizam com as imagens, Grimonprez deixa que 
as próprias imagens comentem a si mesmas e, pelas justaposições que organiza ou pelos contrastes imagem/som, ele realiza uma montagem especializada de 68 minutos. Mistura as imagens de choque (explosões, batidas, corpos cravejados de balas, banhos de sangue), cujo poder de impacto é desarmado pela repetição e pelo excesso, às imagens de ditadores e figuras políticas (Lênin, Stálin, Mao, Castro, Malcom X, militantes palestinos, Leila Khaled, Adel Abdel-Majid, etc.), e às entrevistas de sobreviventes e de documentos sobre a formação da tripulação das companhias aéreas. Todas essas imagens de arquivos são frequentemente acompanhadas por pastiches de músicas de aeroporto, calmantes e comerciais (compostas por David Shea), que recordam que é a própria história o que as mídias vendem; isso tudo entrecortado por publicidades verdadeiras que tornam confusa a diferença entre o que é real e a propaganda. "Em breve, nós tomaremos a realidade por um intervalo publicitário ${ }^{17 ! ", ~ d e-~}$ clara Johan Grimonprez; é apenas uma provocação, a observação da televisão comercial o confirma. A narrativa da construção da história pela televisão (nada de terrorismo sem mídia, nada de informação sem acontecimentos) é acompanhada de um comentário inspirado em um romance de Don DeLillo (Mao // e White Noise) que compara especialmente o destino de um escritor com o de um terrorista, com imagens que evocam uma intimidade autobiográfica. É entre esse vai e vem entre a narrativa da intimidade, as representações de felicidade e de despreocupação (tais como o american way of life as difunde), e a perspectiva vertiginosa das imagens de mortes violentas - que nos remetem ao ex-time ${ }^{18}$, ao de fora, ao outro, ao responsável, ao estrangeiro em sofrimento ${ }^{19}$-, que se realiza, no espírito do espectador, a consciência de uma história construída pelas mídias como uma avalanche de catástrofes provocadas pelo outro, pelo campo adversário, pelo estrangeiro. A construção maniqueísta desta história (Estados Unidos/União Soviética) salta aos olhos ainda que rompida por essas imagens tão estereotipadas.

A catástrofe e o terror como espetáculo, o desastre como objeto do desejo, a encenação apoiada no horror, podem constituir uma história dos povos que seja válida? As imagens do mundo desviadas de sua história, a atualidade tratada como um clipe, e aí está o "nascimento da indiferença" ${ }^{20}$. Os artistas trabalham para dar uma nova chance à História quando propõem um tratamento diferente do arquivo em relação ao conduzido pela propaganda do Estado ou pelo marketing midiático; eles o fazem sem "edificar a moral" e, inversamente, deixam o espectador construir seu próprio campo crítico. 
À margem desses reprocessamentos de arquivos fotográficos, cinematográficos ou televisuais, alguns artistas escolhem resolutamente inscrever-se em uma prática de vídeo documentário, propondo uma alternativa à história escrita pelos centros do poder. É essa história paralela que constrói os grupos militantes dos anos 1970 que, por sua vez, fabricam os arquivos que podem ajudar a reconstruir um olhar realmente informado sobre os acontecimentos ou sobre as situações significativas de uma história; foi o que fizeram mais recentemente Harun Farocki e Andrei Ujica, no Videogramas de uma revolução (1992), em que mostram diversas fontes de imagens relatando a revolução romena e o fim do império Ceausescu.

Essa prática documentária, retomando por sua conta a história do cinema documental (mas sem querer, como ele, propor uma visão de mundo elaborada com, por vezes, o desejo não dissimulado de construir a História), e as práticas da televisão investigativa (ainda mais em contato com a atualidade e com os dispositivos mais simples e mais visíveis), vem encontrando cada vez mais lugar no espaço da arte. Não seria necessário reinjetar, no campo da arte, as doses de realidade cuja existência ela, por vezes, esqueceu (confinada que estava em posturas narcisistas e individualistas), e permitir que reencontre as energias e as motivações relacionadas à urgência de tornar as coisas do mundo perceptíveis e menos confusas? A escola documentária é igualmente uma escola do olhar e da atenção, da preocupação com o outro quando a preocupação consigo passa também por esse outro; ela permite regenerar as fórmulas e as redundâncias gastas. Assim, uma artista como Ursula Biemann, realiza um vídeo documentário, Performing the border (1999), que confirma essa função informativa que o vídeo pode adquirir, assim que ponha seu "olhar" sobre as coisas. Pode ser que este seja um efeito da queda do muro de Berlim e do Império Soviético e a necessidade de imagens e de representação que esses acontecimentos excepcionais do fim dos anos 1980 tenham gerado. Em todo caso, o tema de Biemann é também a fronteira, aquilo que separa os homens e as economias entre México e Estados Unidos em Juarez, fronteira norte-sul, onde a violência econômica não compete com a do Leste-Oeste simbolizado pelo muro ${ }^{21}$. Separação essa considerada a partir do ponto de vista das mulheres mexicanas, que sofrem de uma dupla separação, a da economia geral do México em relação aos Estados Unidos, e aquela da economia doméstica na qual têm um papel inferior (em sua dignidade) e fundamental (elas são o pilar da família). É sobre o terreno da sexualidade que se dá a separação e o limite nos quais a prostituição e o assassinato se instalam e cristalizam a diferença econômica; a mão de 
obra barata mexicana é explorada pelas indústrias americanas instaladas ao longo da fronteira. Ursula Biemann questiona esse espaço específico que é o da fronteira, tanto sob o plano real quanto sob o plano simbólico.

Palavras, testemunhos, comentários são igualmente aspectos característicos do trabalho de Chris Marker, Robert Wiseman ou Robert Kramer, autorizados a partir do aparecimento do som direto sincrônico dos anos 1960; é então uma história que prossegue, à margem do cinema e à margem das artes plásticas, que vai ao encontro da realidade de comunidades e de geografias abandonadas pelas representações dominantes. Dar visibilidade àquilo que não a tem e que está ameaçado, de fato, de desaparecer. Resistir ao desaparecimento conferindo à imagem a possibilidade de futuro, porque, como escreveu Jacques Rancière, "Nosso presente está aprisionado não tanto pelo ceticismo, como se diz muito frequentemente, mas sim pela negação $22 "$

Da reciclagem à fabricação de arquivos, os artistas participam da constituição e da reconstituição da memória dos povos e das pessoas; o vídeo é uma ferramenta privilegiada para este trabalho notavelmente temporal, pois permite a anamnese e atualiza o desaparecimento.

\section{Uma mídia da anamnese}

A fotografia, e depois o cinema, serviram de prolongamento da memória, isso quando não são inteiramente substituídos por ela. Chris Marker se pergunta em seu filme Sans Soleil como é possível se lembrar de tudo que vivemos sem que se fotografe, filme ou registre. As imagens que ele filma são sua memória. É também o que Jonas Mekas diz de outra maneira: “Eu filmo porque não tenho memória, só posso me lembrar do que filmo, e as lembranças me vêm quando revejo as imagens. Talvez seja por isso no fundo que comecei a filmar, porque não consigo me lembrar das coisas" 23 . O vídeo, nesse sentido, desempenha a mesma função, e os vídeos de família são a melhor prova disso; é até mesmo possível se descarregar de sua memória e confiá-la ao suporte eletrônico, onde ela pode permanecer por muito tempo, latente, sem ser solicitada: o que importa é saber que as lembranças estão lá, e que basta acionar (passar a faixa do vídeo) para se recordar, como lembrar de uma recordação da memória quando a necessidade se faz sentir. Nesse sentido, a memória informática desempenha, por sua vez, o mesmo papel, o de uma descarga da memória, com um sistema de armazenagem que leva 
em consideração a importância ou o frescor da informação que é depositada - memória RAM, memória cache e memória de vídeo designam as capacidades técnicas dos computadores.

Em seguida aos seus parentes mais próximos em sais de prata (a fotografia e o cinema) e em dupla com a informática, o vídeo, como mídia e como dispositivo espacial, é utilizado muito frequentemente como ferramenta de anamnese. Porque, ao contrário da fotografia e do cinema que atualizam, no momento em que aparecem, algo que aconteceu, a imagem de vídeo está sempre potencialmente no presente do seu registro ou da sua difusão. Da mesma maneira que a consciência do presente se faz no cérebro pela lembrança constante de recordações a curto ou longo prazo, o vídeo "desarmazena" suas reservas ou camadas potenciais de imagens, às quais a matéria "pixelizada" dá momentaneamente forma. A partir desta potencialidade, o vídeo joga todos os jogos, dos mais clássicos aos mais sofisticados tecnicamente, interrogando o arquivo como o cinema pode fazê-lo, colocando em cena os modos de aparecimento da imagem como nas rememorações (indecisão ou precisão da imagem), organizando um espaço propício à recordação, a todas as recordações. Numerosos artistas exploraram e continuam explorando essa proximidade entre vídeo e processo da memória. Thierry Kuntzel (a série de Nostos I, II e III, Still), Slobodan Pajic e o conjunto da obra de Bill Viola bem como Christian Chatel e Régis Cotentin vindos de uma geração mais jovem (essa precisão visa confirmar que a questão da memória preocupa ainda as práticas mais recentes) trabalharam e ainda trabalham nesse sentido. Os dois últimos criam imagens e dispositivos que tornam visíveis na obra a recordação e o sonho, sob a forma de imagens filtradas, projetadas, parciais, sombrias, quase irreconhecíveis; teatros da memória, o espectador nele projeta suas próprias histórias íntimas ou fantasmáticas e, fazendo um verdadeiro esforço de rememoração, não seriam apenas aquelas imagens que ele tem sob seus olhos. Régis Contentin procura, em seu último vídeo Subjectile 2001, dar forma a corpos ausentes - irmãs desaparecidas na infância - que ele procura nas imagens consideradas como buracos, fendas abertas, restos de uma memória impossível de costurar. Todos estes artistas exploram a qualidade do meio. É necessário lembrar que, por sua natureza tecnológica, seus componentes plásticos (formais), seu suporte efêmero, sua natureza paradoxal de ser a um só tempo moderno (no sentido atual) e arcaico (por sua técnica de registro primitiva), o vídeo propõe modos de funcionamento (aparecimentos, pontos, camadas, deslizamentos) próximos daqueles verificados na memória em ação. Ele se apresenta sob a forma de um fluxo ininterrupto que capta permanentemente 
a imagem do cérebro. A imagem eletrônica está sempre em movimento, e esse movimento condiciona a percepção que podemos ter dela. Ela produz uma imagem evanescente, propícia para dar conta de movimentos sutis de desaparecimento da forma e do pensamento. A escassa fisicalidade deste meio torna possível um tipo de suspensão da matéria favorável à expressão de uma forma de pensamento ${ }^{24}$. A instabilidade e a incompletude de sua imagem requerem, da parte do observador, a mobilização de sua memória e que mantenha em alerta permanente seu sistema perceptivo. A própria percepção é modificada frente à tela eletrônica: a impressão deixada pelos corpos luminosos é tratada de tal modo (em relação ao modelo das imagens mecânicas tradicionais da fotografia e da cinematografia) que os limiares do reconhecimento se encontram deslocados de maneira mais ou menos sensível segundo as manipulações operadas sobre os sinais, diminuindo assim a identificação mimética dos objetos de referência. O vídeo, em seu próprio meio, propõe uma nova paisagem de percepção na qual o espaço e o tempo dão conta de um pensamento em imagem.

Já com Victor Burgin (1941, Grã-Bretanha), é com outra forma de trabalho mnemônico que lidamos. Suas preocupações referem-se à história da arte, ao cinema e à psicanálise, tendendo a solicitar as regiões profundas da intimidade psíquica dos visitantes. Em duas peças de faturas muito diferentes em aspecto, o artista coloca em tensão categorias de imagens bem afastadas em forma e em conteúdo, criando "uma justaposição geográfica de lugares distantes no 'espaço psíquico'," 25 como ele mesmo afirma, para engajar o espectador em um estado em que a própria obra lhe apareça como uma lembrança pessoal. Remembering, repeating (1995), é uma instalação com duas videoprojeções que ficam uma em frente à outra, e um loop de imagens de 3 minutos que dá o ritmo da peça. Sobre uma das telas, às imagens noturnas do metrô aéreo de Paris se alternam imagens de pessoas circulando sobre a esteira rolante do metrô de Montparnasse: toda uma humanidade desfila em forma de multidão solitária. Sobre outra tela, as imagens em preto e branco extraídas de Pépé le moko (Julien Duvivier), mostram Jean Gabin correndo em um canto da Casbah ${ }^{26}$ em Alger, tropeçando e caindo enquanto uma mulher de véu se levanta: a queda se repete, assim, ao infinito. Reconhecendo-se ou não o filme, o contexto (o cenário) do plano isolado é exótico, colonial, dramático e ficcional; a imagem de outra tela, por efeito reativo, parece comum, urbana, abandonada, imigrante, contemporânea. E lembramos que Pépé corre atrás de sua bela, e que essa corrida o levará à morte fora da Casbah que ele tanto conhece. A queda mostrada 
aqui é a metáfora do destino da personagem na ficção. Essa história, essa ficção antiga, essa lembrança do cinema representa uma memória em relação à imagem atual, e é isso que sentimos quando imergimos na peça, para além da anterioridade objetiva de uma em relação a outra, e para além da relação ficção/realidade que as distingue. Alguma coisa torna as duas imagens familiares uma à outra, e é provavelmente a gênese do trabalho que esclarece essa familiaridade: Victor Burgin realizou esse projeto enquanto os atentados islâmicos assolavam Paris. Para ele, a história colonial francesa está inscrita na diversidade geográfica da origem das pessoas que passam sobre a esteira rolante do metrô de Montparnasse. E é então que compreendemos como esses rostos impassíveis e reservados elaboram o retrato de uma cidade certamente carregada de história, mas de uma história que não é feita de sucesso e leveza; seus rostos nos fazem pensar e projetar sobre eles a ficção que está à sua frente, e o processo mnemônico e reflexivo é então ativado.

Em uma de suas últimas realizações, já citada a propósito da visão panóptica, Burgin utiliza novamente essa figura de tela-lembrança tal como Freud designava as recordações que impedem o acesso àquelas memórias cuja rememoração será muito dolorosa, mas em outra configuração. Nietzsche's Paris (2000), é uma fita de vídeo de 10 minutos projetada sobre uma parede. As imagens mostram filmagens panorâmicas da Bibliothèque de France em Paris a partir de pontos de vista diferentes. Rapidamente surge a estranheza dessas imagens: elas são filmadas em preto e branco, nenhum vestígio de vida aparece, tudo ali está congelado. Será um vídeo panorâmico realizado a partir de uma fotografia panorâmica? Pontuada por uma trilha sonora que nos deixa ouvir trechos de Alcina, e de Ariodante de Haendel, e de silêncios muito marcados, surge outra imagem em completa oposição aos panoramas: um plano fixo, em cores, representando uma mulher de vestido escuro do final do século 19, sentada em um banco, em um vale de vegetação que se agita sob a brisa leve, olhar dirigido para a câmera, à distância. Em um momento, as caixas de texto aparecem: “Eu vi um escritório de trabalho muito agradável, repleto de livros e flores. Havia duas salas adjacentes e, indo e vindo em torno de nós, os colegas em plena reflexão formavam um círculo intelectual ao mesmo tempo alegre e sério". Este texto identifica uma escritura e uma personagem, uma ficção consagrada nesses planos - descritivos, mas sem projeto - de uma Paris petrificada sob o olhar de uma medusa panóptica e, portanto, fascinante. Novamente, Victor Burgin coloca as condições de uma rememoração "em tempo real", proporcionando os desvios entre os diferentes registros 
da imagem, e utilizando a música como prática do pensamento. O panorama realizado no interior desta arquitetura lembra o fantasma - inconsciente? - de Plan Voisin (1925) de Le Corbusier, projeto megalomaníaco de beleza assustadora que consistia em derrubar Paris para edificar as cidades-torres monumentais. Ele dá uma imagem congelada e inviável da cidade moderna, na qual o corpo é capturado pela armadilha de sua posição central, sem possibilidade de intercâmbio com o que vê. Além disso, a relação entre movimento e imobilidade confere um estatuto muito estranho à imagem: What is this? $\mathrm{E}$ a grande questão que a linguagem coloca à imagem. De fato, Victor Burgin transformou a sequência filmada em imagens fixas, modificou-as e depois as reanimou digitalmente para produzir o movimento panorâmico. $\mathrm{O}$ plano da mulher de outra época alivia o espectador dessa visão sintética sem o verdadeiro olhar, porque apesar de sua fixidez, ele exprime o estremecimento do ser vivo. Entretanto, não há aqui ponto de melancolia ou de ressentimento - trata-se de Nietzsche, o título já havia advertido o visitante - e não de um mausoléu erguido ao filósofo da modernidade, mas de uma homenagem a uma história de amor, tão breve quanto fulgurante, aquela de Lou Salomé, Nietzsche e do amigo Paul Rée, que sustentaram durante um tempo o projeto de fazer um ménage à trois em Paris. O projeto não se realizou, e o amor acabou, mas Lou Salomé teve um sonho, que é narrado por ela na fita de vídeo. Não é indispensável conhecer toda a história para apreciar a proposição estética de Victor Burgin, na qual sentimento e modernidade se confrontam, e de alcançar esse estado de disponibilidade de espírito que permite organizar as sensações em uma construção mental em que sua própria bagagem, afetiva e conceitual, alimenta a percepção do trabalho.

Se as lembranças se inscrevem em um lugar, como o prova Simonide, sua rememoração deve mobilizar imaginário e imaginação, como o demonstra Victor Burgin, por meio de uma memória que não abranja diretamente sua vivência pessoal, mas sua experiência intelectual e imaginária. Em todo caso, escreve Clément Rosset ${ }^{27}$ : "A memória não se deixa enganar, porque ela procura um objeto singular que, como não pode ser confundido com nenhum outro, é, de algum modo, inesquecível por natureza", e ele esclarece sua tese: "como a memória, a imaginação é tensionada em direção a um determinado objeto [...] que ela tenta dotar de uma quase-presença, ao sugerir-lhe uma 'representação' (ou um retorno da ausência ao aqui e agora). Mas esse esforço da imaginação só pode se realizar perfeitamente pelos atributos do real, quer dizer, pela aparição, em pessoa, do objeto imaginado." É com um tipo de dom 
do real que o jovem artista Anri Sala (1974, Albânia) tem que negociar quando reencontra um velho cinejornal no qual sua mãe é entrevistada por ocasião de um congresso da juventude comunista: esse filme mudo vai servir de eixo mnemônico para o vídeo Intervista (1998), no qual ele procura conhecer, encontrar e compreender os traços de sua própria história por meio de sua mãe, relacionada à história da Albânia comunista - ainda carregada de silêncio. E é justamente pela decodificação do silêncio do filme encontrado que começa o trabalho do vídeo, com a leitura dos lábios dos protagonistas realizada por pessoas surdas: as palavras em linguagem clara recitavam versos de uma utopia que sabemos o quanto foi manipulada por um interesse que estava longe de ser partilhado. Anri Sala, com ternura e atenção, pede esclarecimentos à mãe, que as dá serenamente. Porque nada é simples, o trajeto de uma vida passa por compromissos, por esperanças, crenças e atos que podem parecer anacrônicos ou contraditórios. Este trabalho é fascinante porque, às perguntas teóricas e morais colocadas e deixadas um pouco de lado (sem, no entanto as excluir), a mãe responde com argumentos baseados em uma pulsão de vida e de generosidade por um país e por seus próprios filhos. A forma escolhida pelo artista é também múltipla, ela toma emprestada da história do documentário, comenta e interroga, mas a mistura à ficção, cita suportes diversos, do cinema à televisão: tudo é adequado para usar nessa pesquisa conduzida com urgência (esse trabalho se dá durante uma situação turbulenta na Albânia), que sabe que o tempo da inocência terminou há tempos. Anri Sala prossegue com esse trabalho de confrontação entre discurso e realidade, procurando sublinhar as feridas que habitam os homens cuja história ele evoca, que é sempre mais ou menos a nossa.

\section{Um médium "entre"}

O vídeo é um sistema de imagens tecnológicas que se beneficia, ou se beneficiou de um estatuto particular, tanto do ponto de vista histórico quanto do estético. Esse estatuto particular ocupa uma posição entremeio, de intermediário, de "intermédio" como diz Philippe Dubois, entre o cinema (que de uma "invenção sem futuro" de seus primórdios, acabou por adquirir seus títulos de nobreza e a pertencer, em seus melhores momentos, à grande arte) e a informática (que sem ter produzido uma estética real como meio, parece abrir perspectivas de absorção generalizada, assim como difunde os modos de pensamento que ultrapassam 
largamente o campo da arte - e aquele das imagens em particular). "Como se o vídeo só tivesse sido um parêntese, frágil e transitório, marginal, entre dois universos de imagens fortes e decisivas sob qualquer ponto de vista ${ }^{28 ", ~ e l e ~ t a m b e ́ m ~ s e ~ b e n e f i c i o u ~ d a ~ i m p u n i d a d e . ~ N a ̃ o ~}$ pertencendo às grandes categorias artísticas, ele pode permitir-se impertinências ou inconsequências, audácias tanto conceituais quanto formais, hoje já inclusas nos hábitos e práticas artísticas num sentido amplo. Sua posição é, portanto, de estar "entre": entre a imagem e a ausência de imagem, entre o analógico e o digital, entre o cinema e ele mesmo, entre objeto e processo, entre visível e invisível, entre o ao vivo e o pré-gravado, entre o móvel e o imóvel, entre o fora e o dentro, entre o acima e o abaixo, entre a vigília e o sono... Essa posição lhe permite passar discretamente por todos os lugares e absorver as coisas insignificantes, sem importância, menores (Michel Blazy filma os insetos circulando no mato ou sobre as paredes), mesmo que eles não sejam mais do que pequenos gestos artísticos (Boris Achour registra suas Action-peau com uma câmera de mão, rápida, sem formalismos; Franck David filma situações muito simples em visões imperfeitas e ambíguas) que podem, por vezes, resultar em uma imagem um tanto indiferente, até mesmo preguiçosa, mas sem gravidade. Porque a preguiça também é uma postura que pode conduzir a esta atenção distraída, que permite captar aquilo que uma atenção concentrada e um dispositivo técnico muito pesado teriam deixado escapar. A leveza da falta do saber-fazer e da atividade profissional, leveza da proposta, leveza do dispositivo: essa leveza tem, por vezes, um caráter regressivo, que já foi citado aqui, e que reivindica o ponto de vista do idiota, quer dizer, daquele que é ignorante, que não é conhecedor. Os sacos plásticos inflados pelo vento ou pelas saídas de ar do metrô de Boris Achour $^{29}$ são uma maneira de fazer, com o quase nada do real, um objeto poético próximo do Haïku japonês: a forma, a técnica, os gestos, estão em "fase econômica" e podem, portanto, produzir um objeto artístico equilibrado, livre como o ar que entra no saco.

Bill Viola foi um videasta do entremeio por excelência e, em seu trabalho, o vídeo é a ferramenta ideal para traduzir os estados mentais intermediários entre a vigília e o sono, a vida e a morte, a realidade e a ilusão: o conjunto de sua obra se situa nesse entremeio, nessa zona de indecidibilidade entre a consciência e a inconsciência, o controle e o abandono. Instalações como Room for St. John of the Cross (1983), Threshold (1992) ou Tiny Death (1993) são dispositivos nos quais "opera-se o intercâmbio entre um espaço mental e uma realidade material", 
como definiu Anne-Marie Duguet. Esta estética do entremeio se aplica ao corpo na peça The Messenger de 1996 (que é associada à The Crossing, tríptico de Trilogy); que apresenta um movimento na imagem que conduz da desfiguração ao desaparecimento de um corpo para, em seguida, partir na direção da reconfiguração deste corpo. Para isso, Bill Viola utiliza um meio com o qual é familiarizado, a água, dentro da qual se afunda um corpo nu cujo invólucro visível parece se dissolver no redemoinho da superfície, até perder toda a aparência humana. A integridade dessa aparência não se realiza até que o corpo venha respirar na superfície da água onde ele retoma forma e cor. É na duração de uma respiração, de uma apneia, que Viola torna visível a passagem da forma ao informe, da vida à morte, da fusão à dispersão. É também entre os interstícios entre visibilidade e audibilidade, fisicalidade e evanescência, aparição e desaparição, memória e presença, que se situa uma boa parte do trabalho videográfico de Gary Hill. E em seguida, há também os artistas que inscreveram formal e estruturalmente o entremeio em suas imagens: Stan Douglas, por exemplo, em sua peça Nu-tka (1996), e Marcel Dinahet, no núcleo de seu trabalho nos últimos anos. Como se a imagem hesitasse em escolher um ponto de vista, como se tivesse perdido a segurança do cinema - e é certamente o caso - ela busca entre duas direções, a direita e a esquerda, o alto e o baixo, a emersão ou a imersão, ela se desata do corpo e do olhar físico. Nesta peça tanto notável quanto enigmática, Stan Douglas sobrepõe dois filmes, que são duas panorâmicas, animadas por um movimento oposto, descrevendo uma paisagem da Ilha Nootka, no Canadá, onde aconteceram os primeiros massacres entre índios e europeus. Duas vezes a cada rotação de $360^{\circ}$, as panorâmicas se sobrepõem exatamente e oferecem uma imagem legível, prevista, porém fugaz da paisagem, enquanto que os dois discursos do mesmo modo sobrepostos falam de uma única voz. Entre a visibilidade e a interferência se situa a memória de uma história trágica: nenhuma plenitude para uma imagem cuja serenidade e total visibilidade não fariam sentido. As imagens de Stan Douglas correspondem a uma elaboração mental, e não técnica (defasagem entre duas instâncias incompatíveis: a terra e os homens, o poder e sua violência), e a um projeto conceitual que se atualiza em duas panorâmicas contraditórias.

Marcel Dinahet situa sua posição sobre as bordas do litoral e sobre a linha de flutuação dos grandes portos atlânticos, em seus bem nomeados trabalhos Flottaisons. ${ }^{30}$ Filmados a partir de uma caixa de mergulho, as imagens incorporam a respiração, de onde sentimos toda a 
energia que ela empenha, e a dificuldade que dela decorre. No mesmo espírito, mas em outras águas, o trabalho realizado em Chipre no ano de 2000 produz um tipo de imagem "interface", entre acima e abaixo, a terra e uma zona industrial, a terra e sua exploração, a natureza e a máquina. Essa imagem dupla corresponde a uma visão impossível, afetada pela ubiquidade, cortada ao meio pela superfície da água, lâmina afiada que recorta o limite entre o visível e o invisível, o mundo de dentro e o mundo de fora, separados, radicalmente separados. O real e seu reflexo se confundem dentro do movimento caótico e jamais estável do enquadramento, onde a horizontalidade parece salientar outro mundo. Flutuar como uma rolha é deixar-se levar pelas correntes e pelas forças, sem que se possa controlá-las, e ver o que isso produz: às vezes, beira o risco de desaparecer e de se afogar, às vezes, sentimos uma intensa alegria, aquela de ser levantado, arrebatado, arrancado da força da gravidade pela potência da água, como exprime o vídeo de Maria Friberg, Blown Out, de 1999.

O entremeio não é um lugar de fato; sem lugar e sem espaço, o vídeo não tem limites, não está nem cá nem lá. Ele pode cometer excessos ao escolher a discrição do infrafino ${ }^{31}$ ou, inversamente, a pretensão da grandiloquência. Como a rã que quer fazer-se maior que o boi, o vídeo enfatiza, por vezes em excesso, a visibilidade de seu aparecer para compensar a ameaça de seu desaparecimento, que sempre o acompanha. Mas é também graças a essa falta de lugar e de definição que o vídeo pode constituir uma ferramenta particularmente adaptada à diversidade das práticas artísticas contemporâneas. E se o vídeo levou tanto tempo para ser reconhecido, é justamente porque não tinha seu próprio lugar; ele o tem agora, e de maneira ampla, pelas mesmas razões. Entre aparecimento e desaparecimento, é o entremeio ontológico do vídeo que os artistas sentiram desde o início; os grandes pioneiros (Paik, Vostell, Campus, Viola, Hill, Kuntzel... ) inscreveram o desaparecimento em seu trabalho videográfico, mas podemos dizer igualmente que é em função dessa preocupação, que atravessava todo o campo da arte, que o vídeo, por suas características evanescentes, foi tão usado e considerado como a ferramenta mais apta para traduzir o espírito do tempo. É em razão de o vídeo atravessar e ser atravessado por campos de influência diferentes e heterogêneos a ele mesmo, que ele não está em parte alguma, e que está em toda parte onde se produz um evento artístico, portanto, em todos os campos críticos. Ele goza realmente de um não lugar no processo do formalismo modernista, e é isso que faz dele uma ferramenta tão efetiva ainda hoje. 


\section{Estética do desaparecimento}

O século XX é simultaneamente o século das tecnologias e da indústria da velocidade, e o século onde, como nunca antes, os corpos foram submetidos a uma indústria do aniquilamento, ou seja, a uma programação em grande escala de seu real desaparecimento. Esses dois polos foram colocados em relação por Paul Virilio que, com um tom claramente pessimista, vê também, no aumento exponencial da velocidade, as condições mesmas do esquecimento da consciência de si: "O desenvolvimento das altas velocidades tecnológicas levaria ao desaparecimento da consciência como percepção direta dos fenômenos que nos informam sobre nossa própria existência32". O vídeo não somente ecoa esse problema, como era, no início, o produto dessa relação íntima entre velocidade e desaparecimento. É seu caráter evanescente, sua ontológica evanescência que inscreve o videográfico entre desaparição e desvanecimento, ou seja, entre a aparição como traço de um objeto ausente que, entretanto, existe, mas é abstraído da visão, e a aparição desse objeto como estando em vias de desaparecer, de perder consciência, de se evanescer da consciência e de tornar-se fantasma. Jacques Derrida descreve bem esse tornar-se fantasma da imagem eletrônica quando relata sua experiência de 'televisão' para as entrevistas filmadas que realizou com Bernard Stiegler: "Desde que fomos captados por instrumentos ópticos que não temos nem mesmo necessidade da luz do dia, nós já somos os espectros de uma 'transmissão televisiva'. Nosso desaparecimento já estava lá. Já estávamos entorpecidos por um desaparecimento que promete e antecipadamente rouba outra 'aparição' mágica, uma 're-aparição' fantasmática, na verdade absolutamente miraculosa [...] De antemão somos espectralizados pelo disparo da máquina, agarrados pela espectralidade ${ }^{33}$ ". E o espectro é "um rastro que marca previamente o presente de sua ausência"; este espectro assombra numerosas obras videográficas, pois elas são capazes de dar a ver a experiência do desaparecimento no aparecimento da imagem. Midnight Crossing, instalação de Gary Hill realizada em 1997, propõe ao visitante uma experiência de visão no centro de um ofuscamento: um fluxo de imagens fragmentadas, descontínuas, de lembranças antigas, de corpos, uma mulher de costas que se vai, uma cidade oriental, ruínas dificilmente identificáveis, são projetados sobre uma tela. Esta é igualmente difícil de localizar, pois é situada em uma obscuridade muito densa, tão densa, que é rompida por violentos flashes estroboscópios que apagam momentaneamente as imagens da visibilidade, para deixar aparecer a estrutura em forma de andaime que sustenta a tela. A luz ofuscante imprime 
duradouramente o espectro da estrutura sobre a retina do espectador, enquanto as imagens "lembrança" veem sobrepor-se. O espaço da instalação torna-se assim o lugar da projeção do processo psíquico no qual se desenrola a rememoração, o apagamento, o impedimento de ver e de se lembrar etc., como se esse tivesse modificado o espaço real. Uma voz pronuncia as palavras e expressões, uma voz com toda a sua fisicalidade, como sempre ocorre com os vídeos de Gary Hill. A imagem posta à prova em sua apreensão e em sua inibição mergulha o espectador na inquietação e o coloca no território de seus próprios fantasmas. Vemos assim o quanto o sonho e a lembrança são domínios privilegiados dessas transferências, reproduções e outros elementos da substância das imagens.

Como se a condição da imagem contemporânea consistisse, seja para estar em vias de aparecer, seja para estar em vias de desaparecer, em jamais se oferecer, no momento último de sua realização, em seu auge de visibilidade e de plenitude; nesse movimento, as imagens fazem-se e desfazem-se, mesmo quando são fixas e únicas como as pinturas de Gerhard Richter ou as fotografias de Christian Boltanski. Uma imagem na qual sentimos toda a hesitação em se dar por inteiro e que avança, sobretudo como uma aproximação, um tipo de proposição, de possibilidade, um indício, uma sugestão. Quantas imagens contemporâneas exprimem essa aporia da representação analógica? Nelson Henricks é desses artistas que procuram do lado das imagens espectrais uma aparição do não aparente: Murderer's Song (1991), Crush (1997), Times Passes (1998) são vídeos nos quais a presença do corpo é suspensa ao nível da vibração de uma luz, à sua mudança permanente. Dificuldade de existir, de comunicar, de viver as diferenças: razões não faltam para justificar o estado de suspensão das imagens que permanecem no lugar de inscrição de um sofrimento, seja ele qual for. Granular Synthesis, grupo de artistas austríacos, realiza vastas projeções monocromáticas de uma matéria eletrônica vibrante, onde se produzem pequenos eventos que tendem a deixar adivinhar as formas (os espectros), aquelas de rostos, por exemplo. Essas formas visíveis parecem geradas, impulsionadas pela energia da música tecnológica. Os sons penetram muito violentamente, com uma vibração muito próxima daquela que anima a imagem (a não imagem), no interior do corpo do espectador. Em uma concepção absolutamente oposta da velocidade e das intensidades, Annelies Strba (1947, Suíça), propõe em Dawa (2001) uma visão de seu mundo familiar absolutamente espectral, porém serena, traduzida por imagens que somente mantém, dos objetos luminosos, o esplendor das cores e das massas abrandadas, que só mantém do real 
sua lembrança, cujo tratamento videográfico concede uma equivalência sugestiva. Imagens apaziguadas pela distância da lembrança. São sob o carimbo da perda, do déficit e da retirada que se definem essas imagens dos últimos vídeos: essas imagens não são pobres, mas esgotadas pela exibição excessiva e, por tudo exibir, elas procuram se reapropriar de uma razão para aparecer. Elas por vezes também oferecem pouco à visão como os primeiros vídeos que foram alterados pelo tempo e que perderam boa parte do sinal de imagem e som; imagens que assinalam uma arqueologia, do meio e da memória.

Podemos então pensar que o vídeo esgotou suas baterias, que está esvaziado e que as práticas ressaltam que suas imagens estão obsoletas? Uma velha canção, velho refrão que não traz nada ao pensamento da arte que se curva às leis da novidade. Esta obra, que tentou fazer um balanço ao identificar os contornos daquilo que o videográfico pode trazer em termos de questionamento, de proposição de dispositivos e de reconfiguração da imagem (e por consequência, do visível) em relação à sua capacidade de representar ou tratar o real e seu imaginário, não é um mausoléu em homenagem ao vídeo, mas antes elabora a constatação das transformações que ele suscitou no centro das práticas artísticas da segunda metade do século XX. Se o vídeo não deixou de trabalhar e de ser trabalhado pelo desaparecimento, é porque na época na qual apareceu não tinha ainda essa urgência histórica e antropológica para confrontar-se. Ele constituiu uma ferramenta particularmente adaptada para elaborar novas formulações da nossa relação com um mundo cada vez mais insaciável, rápido e incontrolável, esmagado pelo peso de uma memória onde as referências estão cada vez mais difíceis de identificar. As referências não são mais tão claras, mas com frequência, ao menos, já o sabemos.

É finalmente no todo digital que aconteceu a última dispersão do videográfico - mas poderíamos dizer também do fotográfico, do cinematográfico e de toda imagem que se situa no regime do analógico - o que confirma não tanto seu desaparecimento, mas antes sua absorção por outro sistema tecnológico.

\section{Desaparecimento no todo digital}

A tecnologia digital traz com ela um campo conceitual muito específico ainda não abordado aqui, mesmo se certos de seus posicionamentos foram prefigurados pelos sistemas de imagens precedentes, em particular pelo sistema videográfico. Ao mesmo tempo, ela trouxe, em 
tempo muito curto, novas questões e novos problemas. O entusiasmo ligado à novidade tecnológica rapidamente percebeu, no sistema de codificação informática, a solução final para a persistente questão da memória, da memorização e da manutenção da informação. Também é verdade que, somente na esfera do computador, a própria palavra memória nunca foi tão utilizada - assim que as primeiras dificuldades de acessar essa memória foram percebidas. Hervé Fischer assinala, em artigo publicado na imprensa em 1999, todo o paradoxo do digital e do esquecimento: "podemos ainda ler os manuscritos do mar Morto, mas não temos mais nenhum meio de ler os primeiros CD-ROM dos anos 1980: os leitores e os computadores da época não existem mais." ${ }^{34}$ Essa questão ultrapassa largamente a esfera da arte porque diz respeito tanto às sociedades quanto à gestão de suas memórias; nesse caso, os domínios políticos e econômicos deverão se responsabilizar frente a uma fé no digital que corre o risco, não previsto, da amnésia das máquinas. Com efeito, se os homens descarregam em suas máquinas grande parte de suas memórias, é necessário procurar saber, se não o porquê, ao menos o que esse descarregamento libera no funcionamento cerebral de indivíduos ou de grupos, em relação aos riscos da perda de informação próprios aos avanços tecnológicos. O esquecimento é necessário ao bom funcionamento da memória, mas o que acontecerá com os buracos na memória dos computadores?

A título de prevenção, a artista alemã Ute Friederike Jürß (1962), nomeou uma instalação de You Never Know the Whole Story (2000). Esse trabalho, que consiste em três videoprojeções de grande formato postas lado-a-lado, indica o quanto o vídeo e o digital encontraram usos em projetos que não acentuam nem a realidade virtual, nem as redes de comunicação, mas que, no entanto, colocam questões ligadas a esses domínios em um dispositivo onde a imagem analógica e sua manipulação digital configuram modelos de imagens de uma nova ordem. E qual seria esta? Três fotografias (isso não é muito claro) entre a mobilidade e a imobilidade tratam, em preto e branco, acontecimentos ligados à atualidade "sensacional": alguns "tableaux vivants" (quadros vivos) exibem personagens em situações extremas - pessoas encapuzadas e armadas, detenção, discussão violenta - que, sem aludirem a um acontecimento preciso, dizem respeito a estereótipos de gênero. Essas imagens saturadas, tomadas de muito perto conforme os códigos fotográficos da imprensa popular e das grandes reportagens. Os personagens não se mexem. Na verdade, eles se movimentam muito pouco e parecem manter a pose. O espectador aos poucos se dá conta que uma pálpebra pisca, que um corpo 
oscila ligeiramente. Enfim, que não se tratam de fotografias, mas de imagens em movimento. A identificação continua confusa. Um segundo fenômeno estranho surge à consciência do espectador: todos os personagens, homens, mulheres, terroristas e policiais, políticos ou passantes, aparentam um ar familiar que cria uma defasagem entre o que se acredita ver e aquilo que se vê, e então surge a questão: What is this? O enigma impulsiona o pensamento a se informar e compreende-se, então, que a artista interpretou no vídeo o papel de cada um dos personagens cujos modelos encontrou em fotografias da imprensa (o New Yory Times). Ao usar todos os artifícios necessários a essas diferentes interpretações (temas), à maneira de Cindy Sherman (figurino, maquiagem, penteado...), ela se posiciona em um fundo azul (método para realizar incrustações/chroma-keys em vídeo) tantas vezes quanto o número de personagens escolhidos, depois utiliza um aplicativo (Inferno) e um computador potente para construir imagens constituídas de diversos "temas" cuja continuidade ela assegura ao retificar digitalmente a iluminação, a maquiagem e os contrastes e assim simular a fotografia de mídia impressa. Deste modo, um curto instante de drama é concentrado em um gestual, uma atitude e uma cenografia bem codificados; isso parece desacelerar quase como em um instantâneo fotográfico, mas não o faz, de fato: é a duração da pose que produz esse efeito. A densidade do acontecimento se torna sensível pelas diferentes camadas de percepção e de duração com as quais é representado. A imagem de imprensa se abre ali em todo o seu enigma, e o suspense da pose permite que se reflita acerca do automatismo na interpretação e na leitura, que sua visão comumente provoca. Não é tanto a questão da verdade e da autenticidade de uma informação que ainda aparecem aqui - já faz muito tempo que a imagem analógica, em si, não prova mais nada ${ }^{35}$-, mas antes aquela de como os estereótipos orientam os processos de identificação do espectador rumo a uma realidade que lhe é apresentada como tal. É precisamente no núcleo de um dispositivo e de uma imagem híbridos (que se beneficiam da associação muito estreita entre vídeo analógico e digital - para finalmente questionar a fotografia), que tal peça se situa. Esse trabalho franqueia um dos espaços nos quais o videográfico encontra hoje possibilidades de exploração: entre imagens digitais e impressão fotográfica, entre cálculo e vestígio, entre digital e analógico.

De certo modo, a digitalização unifica e suprime as distinções que antes isolavam as mídias em categorias distintas. Por outro lado, permite abrir novos espaços entre essas categorias, algumas das instalações abordadas aqui o demonstram (Kuntzel, Burgin, Vasulka, Jürß): entre 
mobilidade e estagnação, a imagem continua a interrogar os processos mentais e atualizá-los em suas possibilidades virtuais.

Com a possibilidade de criação de imagens digitais, as questões epistemológicas mudam sensivelmente: por exemplo, a grande questão do ponto de vista não corresponde mais tanto às considerações topográficas e proxêmicas - situação do corpo e do olhar em face de um objeto no espaço real - quanto a um ponto de vista estritamente mental e processual. $\mathrm{O}$ ponto de vista e sua função ética se deslocaram e não se restringem mais simplesmente à qualidade do olhar e do movimento do corpo que esse olhar motiva, como ocorria na imagem que se construía na "captura" engajada no mundo visível (uma visão que não era alienada do observador humano): o caso da moral do movimento de câmera (o travelling de Godard) ou da montagem (a montagem proibida de Bazin). A ontologia, tanto fotográfica quanto cinematográfica, já maltratada pelo vídeo, deve atualizar radicalmente seus fundamentos com as novas condições da cultura digital.

A maioria das imagens que forma o digital é de imagens híbridas, e nem sempre é fácil reconhecer grande parte do tratamento digital a que podem ter sido submetidas. Exceto quando expandem o dispositivo e o transformam no fundamento da obra, os artistas utilizam discretamente a informática para atingir um objetivo que se situa fora do discurso tecnológico. Segundo Jean-Louis Boissier, "Todas as artes, sobretudo aquelas que se constituem a partir das máquinas ou dos automatismos, foram tocadas pelo digital. [...] Se essas artes foram profundamente transformadas e frequentemente, contra toda expectativa, reforçadas em suas tradições, elas não adquiriram uma nova especificidade". Desse modo, se o digital pode intervir em todas as etapas técnicas da fabricação de imagens, já que é esse o domínio do qual tratamos aqui, ele não intervém de forma sistemática em toda a cadeia desta fabricação: "Assim que o dispositivo informático acompanha a obra de ponta a ponta, ele tende a manter, para o público, as propriedades instrumentais que tem para os autores e, na ocasião, desconcerta a partilha entre espectador - ou leitor - e autor ${ }^{36 . " ~ S e ~ o ~ c i n e m a ~ d e ~ e x p o s i c ̧ a ̃ o, ~ a ~ i n s t a l a c ̧ a ̃ o ~ e ~ o ~}$ circuito fechado - três modos de inscrição do videográfico no campo da arte contemporânea -, participaram da aproximação entre proposição de artista e construção mental do espectador, também anteciparam o dispositivo interativo no principio de certos projetos digitais que introduzem modos de reflexão, ferramentas conceituais e qualidades de previsão absolutamente específicas. Mas é em torno desses novos dados que se encerra a presente reflexão. 
Para encerrar ainda no registro da memória, pode-se observar que são os artistas da geração do cinema ou do vídeo que se apropriaram mais espontaneamente do controle das ferramentas informáticas assim que perceberam que podiam servir a seus projetos: Muntadas (utiliza a rede em sua peça evolutiva The File Room (1994), para censura e bancos de dados da internet, consulta e alimentação do site), Chris Marker (utiliza a informática em seu CD-Rom Immemory). Esses artistas lançaram mão dessas ferramentas sem arrogância e sem pretensão: inversamente, e do modo mais natural possível, como faz todo artista atual que recorre à técnica disponível para expressar o que ele tem a expressar. No mesmo espirito, Éric Lanz (1962, Suiça), sobrepõe técnica antiga e nova tecnologia ao utilizar um conjunto de ferramentas tradicionais em Outils 1 e Outils 2 (1991), e nele parodiar o princípio de interatividade que é reduzido à seleção, por meio da imagem do objeto a ativar (a mão é a interface entre a ferramenta tradicional, a artesanal e a tecnologia citada). Cécile Le Prado (1956, France) realiza, em Vocatifs (1994), um trabalho interativo a partir da base de dados do 'alto comissariado para refugiados': nomes de crianças desaparecidas na ex-luguslávia que uma leitura sussurrada em servo-croata enumera em curtas composições musicais. Pode-se constatar, em alguns dentre tantos outros dos projetos citados, como a memória está também presa às formas analógicas com forte poder emocional, e como a ferramenta digital pode intervir para tornar o propósito mais eficaz.

Os projetos mais potentes são frequentemente aqueles que trazem com eles o inesquecível da infância. O videográfico definiu uma zona de jogo de grande liberdade com todos os excessos que isso supõe; esperamos que a estética digital saiba ainda relembrar as imagens e atualizar o Fort-Da pensado por Freud um século antes, o que nos assegura que não fiquemos petrificados diante da ausência e desvalidos por nossa impotência de pensar por que, como lembra Umberto Eco, "As dificuldades para construir uma máquina pensante não dependem da dificuldade de fazer uma máquina pensar, mas da nossa própria dificuldade de saber como pensamos. ${ }^{37}$ "A liberdade é uma conquista frequentemente posta em jogo no exercício da arte; e o vídeo foi um instrumento nada negligenciável do exercício dessa liberdade.

\section{Notas}

1 Tradução do capítulo 8: "Histoire, mémoire et disparition - La vidéo entre archive et calcul" In PARFAIT, Françoise. Video: un art contemporain. Editions du Regard: Paris, 2001, pp. 323-356. 
2 O técnica da incrustação em vídeo é comumente conhecida como chroma-key.

3 Robert Walser (1878-1956) foi um escritor suíço, admirado por Stefan Zweig, Walter Benjamin e Franz Kafka. Vítima de um ataque cardíaco, seu corpo foi encontrado no dia de Natal de 1956 (NT).

4 Pierre Legendre, La Fabrique de I'homme occidental, Éditions Mille et une nuits, 1996-2000, p. 12.

5 Thierry Kuntzel em seu catálogo para a Galerie Nationale du Jeu de Paume, Réunion des musées nationaux, 1993, p.89.

6 O Wunderblock, ou o bloco-mágico de notas, é uma "lousa mágica" que "fornece uma superfície receptora, sempre reutilizável como a lousa mágica, mas também com os traços duráveis da inscrição de um bloco de notas comum; resulta no problema que coloca a união de duas funções, repartindo entre duas partes constitutivas - ou sistemas - distintos, porém unidos um ao outro"; Freud vê aí, a maneira "como nosso aparelho psíquico realiza sua função perceptiva". Notiz über den "Wunderblock", publicado em 1925, Résultats, idées, problèms, tome II, PUF, 1985, p. 122

7 Frances Yates, L'Art de la mémoire, Gallimard, 1966.

8 Termo emprestado da análise de individualização de Michel Foucault, no Surveiller et Punir, 1975, p. 195: “ O momento em que passamos de mecanismos históricos-rituais de formação da individualidade a mecanismos científicos - disciplinares, em que o norma tomou lugar do ancestral, e a medida, o lugar do status, substituindo assim a individualidade do homem memorável pela do homem calculável, esse momento em que as ciências do homem se tornam possíveis, é aquele em que foram postas em funcionamento uma nova tecnologia do poder e outra anatomia política do corpo". Tradução Raquel ramalhete para a edição brasileira. Vigiar e punir. Petrópolis; Vozes, 1999, p. 16.

9 Devoirs de mémoires (Deveres de memórias) expressão definida em 2003 no dicionário Larrousse como: "A obrigação moral de testemunhar, individual ou coletivamente, acontecimentos cujo conhecimento e transmissão são considerados necessários para retirar lições do passado". Diz respeito também à responsabilidade moral dos Estados de lembrar a seus cidadãos o sofrimento e a injustiça sofridos por certas populações. O termo surge em 1983 com o livro O Dever de memória (Lisboa: Cotovia, 2010), do escritor Primo Levi em que trata de testemunhos de sobreviventes da segunda guerra mundial (NT).

10 "Les nappes de passé et les couches de réalité". Optou-se pela tradução da versão brasileira de A imagem-tempo de Gilles Deleuze (tradução de Eloisa de Araújo Ribeiro. São Paulo: Brasiliense, 2005, p.248 (NT).

11 François Albera, "Matière et mémoire" em Scope Magazine nº 1, Sur les traces de la mémoire, nov. 1992 - jan.1993, p. 14.

12 Dominique Avron, Le scintillant, Imprensa Universitária de Strasburg, 1994, p. 105. Ele prossegue em sua reflexão: "As questões de uma televisão mais pregnante e ligada ao computador, abordam também esse aspecto. Como reter o que voa? A dificuldade é ainda maior que a volatilidade, que por sua vez, não é uma qualidade isolada, mas dependente das qualidades vibráteis, móveis e diáfanas, do médium audiovisual (...) Essa volatilidade é uma volatilidade romântica: a nostalgia do instante que passa irremediavelmente".

13 En abîme (ou en abyme), é uma expressão francesa usada pela primeira vez por André Gide para se referir às narrativas que contêm outras narrativas dentro de si. Mise en abyme pode aparecer na pintura, no cinema e na literatura (NT).

14 Raymond Bellour, “Les images du monde". L'Entre-Images, Paris: La Différence, 1990, p.204. Edição brasileira: Entre-imagens. Campinas: Papirus, 1997.

15 Michael Foucault, L'archéologie du savoir, Gallimard, 1969, p. 14-15. Edição brasileira: A Arqueologia do Saber. Rio de Janeiro: 
Forense Universitária, 2009.

16 Paul Virilio. Um paysage d'evenement, Galilée, 1996, p. 11. O autor se exprime assim: “( ...) Observemos agora a inversão operar-se sob nossos olhos: ao medo do futuro segue-se o medo do passado como se este último, longe de desaparecer, de se apagar por trás do presente, continuasse a sobrecarregá-lo ou, pior, a contaminá-lo secretamente".

17 Voilà - le monde dans la tête - Musée d'Art Moderne de la Ville de Paris, in Revista Les Inrockuptibles, 2000.

18 Extime e um termo derivado do latim extimus e designa o que é voltado para fora, para acontecimentos externos. O conceito de "Extimidade", foi proposto por Jacques Lacan no Seminário XVI, 1969, em oposição à intimidade. Para o psiquiatra Serge Tisseron, é o desejo de tornar visíveis certos aspectos de si até então considerados como representativos da intimidade.

19 Considerando de uma maneira geral, pois as imagens estão descontextualizadas e não autorizam nem recuo nem análise de situações precisas.

20 Jean-Charles Masséra faz um estudo muito minucioso de Dial H.I.S.T.O.R.Y em seu livro Amour, gloire et CAC 40, Paris: P.O.L, 1999, p. 256-285.

21 Krzystof Wodiczko também realizou uma performance para a cidade fronteira de Tijuana em fevereiro de 2001 (La projection de Tijuana), em que dava a palavra às mulheres frequentemente vindas do sul do México, Chiapas e Oxaca, que fazem a economia barata americana. Os testemunhos registrados graças a um dispositivo de prótese videográfica que enquadrava o rosto das mulheres de muito perto, foram projetados sobre um grande cenotáfio (um memorial fúnebre [NT]) da cidade, o que atribuía um aspecto monumental a essas vozes ignoradas pelas representações midiáticas e abafadas em sua existência social. Espaço público e destino privado se interpenetram para produzir um nível de consciência política, como acontece em geral nas proposições artísticas deste artista.

22 Jacques Rancière, "L'inoubliabe" Arrêt sur histoire, Centro Georges Pompidou, 1997, p. 47.

23 Jonas Mekas em conversa com Nam June Paik. Catálogo "Voilà," Musée d'Art Moderne de la Ville de Paris, 2000, suplemento de Inrockuptibles $n^{\circ} 247$, p.59.

24 "A especificidade videográfica resulta da não materialidade da imagem que permite comunicar diferentes estados psicológicos e mentais (versus a alta definição da imagem fílmica, cinema)." Mona da Vinci, "Video. The Art of observable dreams" em Battock, Ed. New Artist'Video.

25 Catálogo Biennale de Lyon, op., cit., p.160.

26 La Casbah se refere a antiga cidade murada de Alger, capital da Algéria, onde forma um bairro histórico inscrito no Patrimônio Mundial da Humanidade da UNESCO desde 1992 (NT).

27 Clément Rosset, Le réel, l'imaginaire et l'illusoire, (Primeira publicação, 1980), Distance, 2000, p.23-24.

28 Philippe Dubois, "La question vidéo face au cinéma: déplacements esthétiques", em Cinéma et dernières Technologies, sobre a direção de Frank Beau, Philippe Dubois e Gérard Blanc, INA/ De Boeck Université, 1998.

290 "saco plástico inflado pelo vento" é um tema que foi muito trabalhado pelos videastas: dentre outros, Nicolas Moulin, no Ambre, 1999 registra seus espasmos antropomórficos; Jacques-Luis e Danièle Nyst fizeram uma variedade de duendes fantásticos em Saga sachet, 1989. Como se esses invólucros de correntes de ar, essas figuras do "quase nada", tivessem encontrado no vídeo seu suporte mais adequado. 
30 Flutuações (NT).

31 O inframince, para Marcel Duchamp.

32 Paul Virilio, Esthétique de la disparition, Éditions Balland, 1980. Ultima edição: Galilée, 1989, p. 117.

33 Jacques Derrida, Bernard Stiegler, Échographies de la télévision, entretiens filmées. Galilée, INA, 1996, p. 131.

34 Hervé Fischer no jornal Libération de 24 de novembro de 1999, página "Rebonds".

35 Ela pode fazê-lo, no entanto, no domínio da justiça em particular, sob condições de controle do modo de concepção e de realização dessa imagem: a fotografia antropométrica ou o vídeo de vigilância, ou ainda a gravação de testemunhos pela polícia.

36 Jean-Louis Boissier, Revue virtuelle, Actualité du virtuel, CD-Rom, sob a direção de Christine van Assche, Jean-Louis Boissier, Martine Moinot, Centre Georges Pompidou, 1996.

37 Umberto Eco, Entretien, Nouvelles Technologies. Un art sans modèle? Art Press spécial, 1991. 